\title{
Serum iron and vitamin B 12 deficiency could indicate celiac disease by flexible spectral imaging color enhancement
}

\author{
(iD) Seval Akay ${ }^{1}$ \\ (D) Omer Burcak Binicier² \\ (D) Ebru Cakir ${ }^{3}$ \\ (iD) Harun Akar ${ }^{4}$
}

\begin{abstract}
1. Kutahya Health Sciences University, Department of Internal Medicine, Kutahya, Turkey. 2. Tepecik Education and Research Hospital, Department of Gastroenterology, Izmir, Turkey. 3. Katip Celebi University, Departament of Pathology, Izmir, Turkey. 4. Tepecik Education and Research Hospital, Department of Internal Medicine, Izmir, Turkey.
\end{abstract}

\section{SUMMARY}

INTRODUCTION: Celiac disease (CeD) is an autoimmune disease that can be delayed in diagnosis due to the presence of atypical and asymptomatic cases in adulthood. Herein we aimed to study the frequency of $\mathrm{CeD}$ and evaluate whether magnified endoscopy and magnified/FICE (flexible spectral imaging color enhancement) techniques contribute to the diagnosis in patients with serum iron and vitamin B12 deficiency.

METHODS: We evaluated 50 adult patients (10 males and 40 females) who had serum iron and vitamin B12 deficiency, prospectively. All the patients had undergone upper gastrointestinal system endoscopy by the same endoscopist. The second part of the duodenum was evaluated with white light, magnified, and magnified/FICE endoscopy. Biopsy specimens were evaluated by the same pathologist. The specimens diagnosed as CeD were classified according to the Modified Marsh-Oberhuber criteria.

RESULTS: 10 of 50 patients (20\%) were diagnosed as CeD. The average age was $41 \pm 11$ years (20-67 years). Thirty percent of CeD diagnosed patients had typical CeD symptoms. Six of 10 patients (60\%) who were diagnosed as CeD had typical endoscopic images under white lighted endoscopy. All of these 10 patients (100\%) showed villous irregularity, partial villous atrophy, or total villous atrophy consistent with CeD with magnified and magnified/FICE endoscopy.

CONCLUSION: The practical use of magnified/FICE endoscopy allows us to differentiate mucosal abnormalities of the duodenum and minimize false-negative results that indicate normal mucosal findings with conventional endoscopy.

KEYWORDS: Celiac disease. Vitamin B 12 deficiency. Iron deficiency. Image enhancement/methods. Image processing, computer-assisted.

\section{INTRODUCTION}

Celiac disease $(\mathrm{CeD})$ is an autoimmune disease characterized by nonspecific findings and symptoms in adulthood, which may lead to a delay in diagnosis. The diagnosis of this disease, which is considered to be the tip of the iceberg due to nonspecific signs and symptoms, is important because of comorbid conditions and increased risk of malignancy. Sometimes micronutrient deficiency may be the only finding indicative of the diagnosis, and it is the physician's awareness of CeD that is decisive at this point. 
Recognition of the pathogenesis of increased inflammation of the small bowel mucosa in CeD is the starting point. Symptoms are related to the extent of involvement of mucosal lesions rather than the severity of pathology in the proximal small intestinal mucosa. Although the data are insufficient in this regard, lesional pathology is thought to cover $30-50 \%$ of the entire small bowel mucosa ${ }^{1}$. Therefore, it should be kept in mind that patients may have latent (or asymptomatic) disease regardless of proximal mucosal damage.

New endoscopic methods may facilitate the diagnosis of CeD with asymptomatic and silent forms. Magnifying endoscopes and digital chromoendoscopic methods are just two of the approaches that have been increasing in use in recent years. Flexible spectral imaging color enhancement (FICE), which is one of the digital chromoendoscopic methods, can be used to convert the mucosal surface structure into virtual newly arranged image structures by using selected wavelengths to obtain more detailed information about the investigated area.

In this study, we planned to conduct a prospective study on the incidence of $\mathrm{CeD}$ and the diagnostic efficacy of magnified endoscopy and FICE in individuals with iron deficiency anemia and vitamin B12 deficiency.

\section{METHODS}

\section{Study Group}

Patients with vitamin B12 and iron deficiency anemia (IDA) who were referred to the Gastroenterology Clinic of İzmir Tepecik Education and Research Hospital for upper gastrointestinal endoscopy and gave written consent to take part in the study were included in this study. They also tested for CeD serology with tissue transglutaminase IgA.

The study was approved by the local ethical committee of İzmir Tepecik Education and Research Hospital (No: 2015/18).

\section{Endoscopic evaluation}

Patients underwent upper gastrointestinal endoscopy after at least 8 hours of fasting and were evaluated with Fujinon EG-490ZW5 high resolution magnified endoscope (Fuji Photo Optical Co., Ltd., Saitama, Japan). A transparent hood was placed on the endoscope tip to ensure good image quality during the procedure and to prevent gastric or duodenal content migration to the area under investigation. After standard videoendoscopic examination by the same endoscopist, standard endoscopic images, magnified and magnified/FICE images of the duodenum were recorded (at least 3 images). Magnification was done by 40-80 times enhancement. Isolated areas in the bulbs and second part of the duodenum were magnified and evaluated, and two biopsies (not four quadrants) were taken for pathological evaluation after imaging.

Evaluation by white light, high resolution magnified endoscope, and FICE images

Endoscopic images were first blindly evaluated under standard white light endoscopy (WLE) and were recorded as with or without any celiac-compatible imaging findings (decrease in the number of circular folds, mosaic/nodular velvety appearance, scalloped duodenal folds, grooves, fissurations, etc.). Subsequently, magnified endoscopy and magnified/FICE images were evaluated and the findings were divided into three groups, i.e., normal, partial villous atrophy, and total atrophy, and recorded.

\section{Pathological examination:}

Biopsy specimens were placed in a $10 \%$ formol solution and delivered to the pathology department. After macroscopic sampling and standardized close system tissue follow-up, the specimens were embedded into paraffin then sliced into 4-5 micron sections by a semi-automated system. These slices were evaluated by the same pathologist using hematoxylin \& eosin staining. For duodenal biopsies in which intraepithelial lymphocytes were increased, immunohistochemically CD3 antibodies were also applied.

Duodenum samples were evaluated according to the Modified Marsh (Marsh-Oberhuber) classification $^{2}$, and gastritis classification in gastric biopsies was done according to the revised Sydney System ${ }^{3}$ by the same pathologist who was not blinded. Modified Marsh criteria were defined as follows:

Marsh I: infiltrative lesion, normal villous architecture and mucosa, intraepithelial lymphocytes are increased (>40 lymphocytes/enterocytes counted)

Marsh II: hyperplastic lesion, similar to Marsh I, but it also presents crypt hyperplasia

Marsh III: destructive lesion; subdivided into three groups:

Marsh IIIa: partial villous atrophy (mild atrophy) 
Marsh IIIb: subtotal villous atrophy (marked atrophy)

Marsh IIIc: total villous atrophy (complete atrophy)

\section{Statistical analysis}

Statistical analysis of the study was performed using SPSS 22.0 (IBM Statistical Package for Social Sciences software version 22). Categorical variables were compared with the Chi-square test and continuous variables were compared with the student-T test. $\mathrm{P}<0.05$ was considered a statistically significant difference with a $95 \%$ confidence interval.

\section{RESULTS}

The mean age of the patients was $41 \pm 11$ years (2067 years). Of the 50 patients, 10 were males and 40 were females. $\mathrm{CeD}$ was detected in 10 of 50 patients (20\%). Three (30\%) of 10 males and 7 (17.5\%) of 40 females had CeD. Tissue transglutaminase IgA antibody was positive in all 10 celiac patients diagnosed and confirmed by biopsy.

There were no statistically significant differences in hemoglobin, hematocrit, serum iron, ferritin, vitamin B12, and folic acid values between the $\mathrm{CeD}$ and non-CeD groups (Table 1). Moderate and severe chronic inflammation was statistically significantly higher in patients with CeD in duodenal pathology $(\mathrm{p}<0.0001)$. Similarly, neutrophil and eosinophil ratios in the duodenal epithelium were statistically significantly higher in patients with $\mathrm{CeD}(\mathrm{p}<0.0001)$, whereas there were no statistically significant differences between the two groups in the proportion of these cells in lamina propria ( $p>0.5)$. The frequency of Brunner's gland hypertrophy in the duodenum was statistically significantly higher in patients with $\mathrm{CeD}(\mathrm{p}=0.01)$. Intraepithelial lymphocytes were present in all of the patients with CeD, but only in 8 of 40 non-CeD patients $(p<0.5)$.

Pathology results and magnified/FICE endoscopic image results were found to be consistent with CeD in all 10 positive patients. CeD was also excluded by pathology results and magnified/FICE images in all individuals with negative antibody. WLE showed a typical endoscopic appearance in six (60\%) of the 10 patients diagnosed with $\mathrm{CeD}$ (sensitivity $60 \%$, specificity 100\%), with mosaic/nodular velvety appearance, scalloped duodenal folds, grooves, and fissurations. In magnified and magnified/FICE imaging, abnormal mucosal findings suggesting CeD were observed in all 10 patients (villous losses in partial or total atrophy, enlargement due to edema in villous, etc.) (sensitivity $100 \%$, specificity 100\%). Partial atrophy in the villous was histopathologically compatible with Marsh 2 , while total atrophy was consistent with Marsh 3a-3b-3c. The distribution of patients according to the Marsh classification is shown in Table 2.

\section{DISCUSSION}

Celiac disease is a chronic disease that affects the small intestine by gluten ingestion in genetically predisposed patients ${ }^{4}$. CeD can commonly present with atypical symptoms, abdominal bloating, constipation, vomiting, weight loss, decreased fertility in women, and malabsorbtion ${ }^{5-8}$. The distribution of CeD varies across the world. The overall frequency of $\mathrm{CeD}$ is estimated to be $0.5-1 \%^{9,10}$. As wheat and barley are the basis of agriculture in Anatolia, the prevalence of $\mathrm{CeD}$ in our country is $1.3 \%{ }^{11}$.

Micronutrient deficiency is a condition that bothers the person insidiously and often remains behind closed doors. Iron and vitamin B12 deficiency could be ignored in the case of the etiology. CeD could underlie

TABLE 1. LABORATORY VALUES OF PATIENTS WITH AND WITHOUT CED.

\begin{tabular}{|c|c|c|c|c|c|}
\hline & Celiac & $\begin{array}{l}\text { Num- } \\
\text { ber } \\
\text { (n) }\end{array}$ & Average & $\begin{array}{l}\text { Std. De- } \\
\text { viation }\end{array}$ & $p$ \\
\hline \multirow[t]{2}{*}{$\mathrm{HGB}$ (gr/dL) } & none & 40 & 10.37 & 1.706 & $>0.05$ \\
\hline & present & 10 & 10.47 & 1.957 & $>0.05$ \\
\hline \multirow[t]{2}{*}{ HTC (\%) } & none & 40 & 32.54 & 4.359 & $>0.05$ \\
\hline & present & 10 & 33.19 & 5.338 & $>0.05$ \\
\hline \multirow[t]{2}{*}{$M C V(f L)$} & none & 40 & 73.10 & 8.064 & $>0.05$ \\
\hline & present & 10 & 76.95 & 13.537 & $>0.05$ \\
\hline \multirow[t]{2}{*}{ RDW (\%) } & none & 40 & 17.35 & 2,623 & $>0.05$ \\
\hline & present & 10 & 17.06 & 5.515 & $>0.05$ \\
\hline \multirow{2}{*}{$\begin{array}{l}\text { Serum Iron } \\
\text { (ug/dL) }\end{array}$} & none & 40 & 30.425 & 36.7597 & $>0.05$ \\
\hline & present & 10 & 26.600 & 15.7565 & $>0.05$ \\
\hline \multirow{2}{*}{$\begin{array}{l}\text { Ferritin (ug/ } \\
d \mathrm{~L} \text { ) }\end{array}$} & none & 40 & 13.0008 & 13.98593 & $>0.05$ \\
\hline & present & 10 & 18.8690 & 26.10889 & $>0.05$ \\
\hline \multirow{2}{*}{$\begin{array}{l}\text { Vitamin B12 } \\
(\mathrm{pg} / \mathrm{ml})\end{array}$} & none & 40 & 155.7375 & 49.37206 & $>0.05$ \\
\hline & present & 10 & 171.4000 & 66.73363 & $>0.05$ \\
\hline \multirow{2}{*}{$\begin{array}{l}\text { Folate } \\
(\mu \mathrm{mol} / \mathrm{L})\end{array}$} & none & 40 & 7.0065 & 2.42318 & $>0.05$ \\
\hline & present & 10 & 5.7350 & 2.55595 & $>0.05$ \\
\hline
\end{tabular}

TABLE 2. DISTRIBUTION OF CELIAC PATIENTS ACCORDING TO MARSH CLASSIFICATION.

\begin{tabular}{l|l|l|l|l|l|l|l}
\multicolumn{9}{c}{ Marsh } & \multicolumn{3}{c}{ Total } \\
\hline & 0 & 1 & 2 & $3 a$ & $3 b$ & $3 c$ & \\
\hline Celiac & 0 & 0 & 2 & 4 & 2 & 2 & 10 \\
\hline
\end{tabular}


in about $10 \%$ of iron deficiency anemia (IDA) $)^{12,13}$. In a Danish study, newly diagnosed CeD patients had 17\% vitamin B12 deficiency and 39\% IDA ${ }^{14}$. Extraintestinal symptoms and atypical form play an important role in adulthood ${ }^{15}$. In a case report, a patient with chronic anemia was diagnosed with Behçet's disease due to recurrent oral aphthae, probably due to existing micronutrient deficiency, and was subsequently diagnosed with $\mathrm{CeD}^{16}$. In one study, the most common accompanying finding at the time of diagnosis in the advanced age group was found to be anemia in $80 \%$ of cases and osteopenia/bone disease in $70 \%{ }^{17}$. In a study performed by Tesei et al. ${ }^{18}$, on 250 treatment-naive celiac patients and a control group of 176 healthy subjects defining the relationship between antibody presence and diagnosis, serology positive silent CeD was detected in 22 patients $(8.8 \%)$.

Antibodies are of great importance in CeD diagnosis and screening ${ }^{19-22}$. The sensitivity and specificity of antigliadin IgG and IgA antibodies are below 90\%' whereas tissue transglutaminase IgA is around $95 \%{ }^{14-}$ ${ }^{16}$. Tissue transglutaminase IgA is recommended for CeD screening for patients age two years and older ${ }^{17}$. Using a screening test before endoscopic evaluation is of great importance in terms of cost in individuals without typical symptoms, and it is not inconvenient to say that biopsy is not necessary if there is no pathological appearance under magnified/FICE examination in individuals without antibody positivity.

Endoscopic appearance is also important in the diagnosis of CeD. Circular folds are regular in the normal duodenal mucosa, with a vivid appearance in the mucosa. Similarly, the magnified endoscopy and magnified/FICE shows that the villous are regular, do not tend to atrophy, and the capillary structure within it can be selected. Mosaic/nodular velvety appearance, scalloped duodenal folds, grooves, and fissurations, which are typical endoscopic findings for $\mathrm{CeD}$ may lead the endoscopist to the diagnosis of CeD. In the study performed by Uyanıkoğlu et al. ${ }^{23}$, CeD was diagnosed based on endoscopic appearance in 7 (0.035\%) of 1950 patients who underwent endoscopy for any reason. In our study, 6 of 10 patients diagnosed with CeD had typical endoscopic appearance (Figure 1a). The loss of villous is also evident in the magnified and magnified/FICE images of these patients (Figure $1 b, c)$. However, WLE alone is not sufficient for the diagnosis of CeD. In our study, there were 4 patients (40\%) who had celiac disease due to antibody positivity and biopsy but had normal duodenum with WLE. The magnified and magnified/FICE images of these cases were not normal (Figures 2 and 3).

FICE, a digital chromoendoscopic method, has been shown to be a diagnostic endoscopic method with higher sensitivity and specificity than WLE in studies of gastrointestinal lesions such as Barrett's esophagus, early gastric cancer, and colon polyps and their diagnosis ${ }^{24-28}$. In our study, we observed that villous losses (partial, total atrophy, etc.) were clearly observed in the detailed examination of the mucosal structure with magnified and magnified/ FICE methods. Specifically, with magnified/FICE, the character of the tissue is seen in more detail. These data are consistent with the study of Cammorata et al. ${ }^{27}$, and we see that the magnified and magnified/

FIGURE 1. ENDOSCOPIC EVALUATION WITH WHITE LIGHT, MAGNIFIED ENDOSCOPE, AND MAGNIFIED/FICE IN AN INDIVIDUAL WITH CED. (A) MOSAIC AND NODULAR VELVETY APPEARANCE, SCALLOPED DUODENAL FOLDS UNDER WLE. (B) TOTAL ATROPHY OF THE VILLOUS IS SEEN UNDER MAGNIFYING ENDOSCOPY. (C) UNDER MAGNIFIED/FICE IT IS CLEAR THAT VILLOUS ARE COMPLETELY ATROPHIED. HISTOPATHOLOGICAL EVALUATION WAS CONSISTENT WITH MARSH 3B.

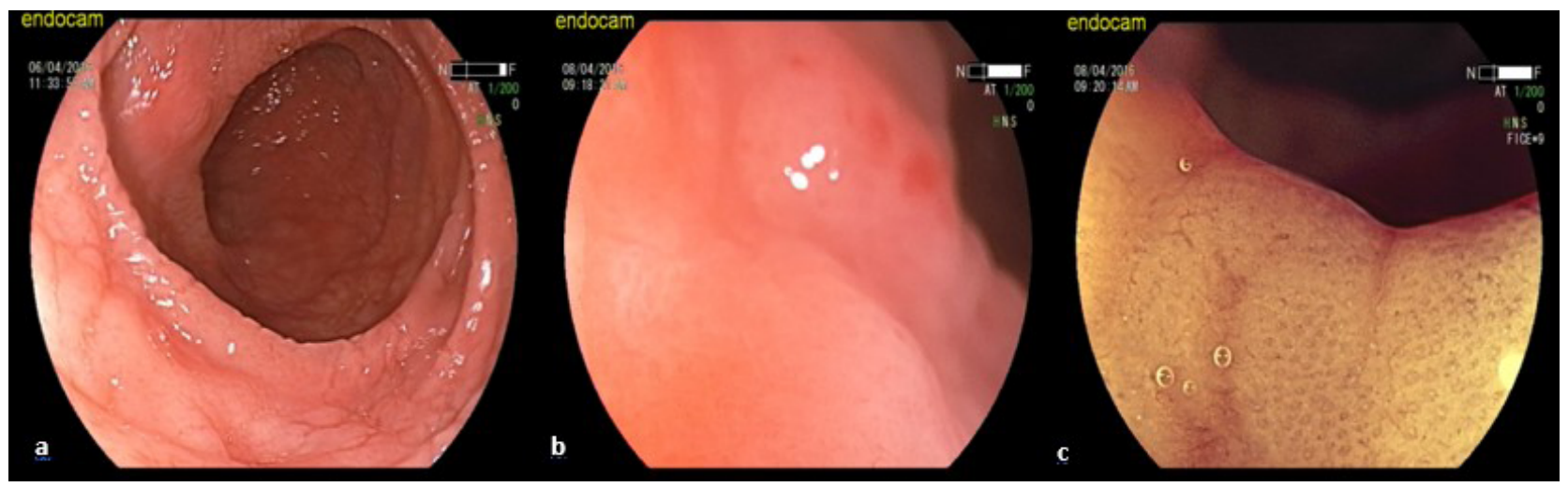


FIGURE 2. (A) IMAGE OF THE DUODENUM WITH WLE SHOWS NORMAL FOLDS AND NO ABNORMAL MUCOSA. (B) IN THE SAME PATIENT'S MAGNIFIED ENDOSCOPY AND (C) MAGNIFIED/FICE IMAGES WE CAN SEE VILLOUS STRUCTURE WAS DISRUPTED AND PARTIAL ATROPHY FINDINGS WERE OBSERVED.

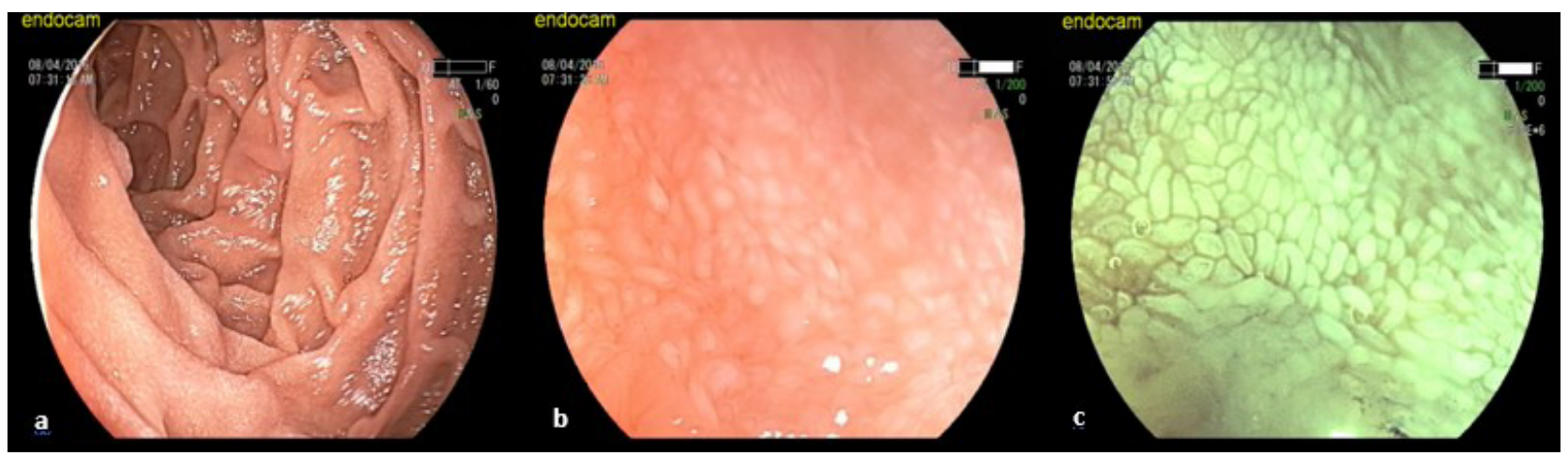

FIGURE 3. (A) IMAGE OF THE DUODENUM WITH WLE SHOWS NORMAL FOLDS AND NO ABNORMAL MUCOSA. (B) MAGNIFIED ENDOSCOPY AND (C) MAGNIFIED/FICE IMAGES OF THE SAME PATIENT SHOW IRRADIATION IN THE VILLOUS AND LOSS OF ORDER. HISTOPATHOLOGICAL EVALUATION WAS CONSISTENT WITH MARSH 2.

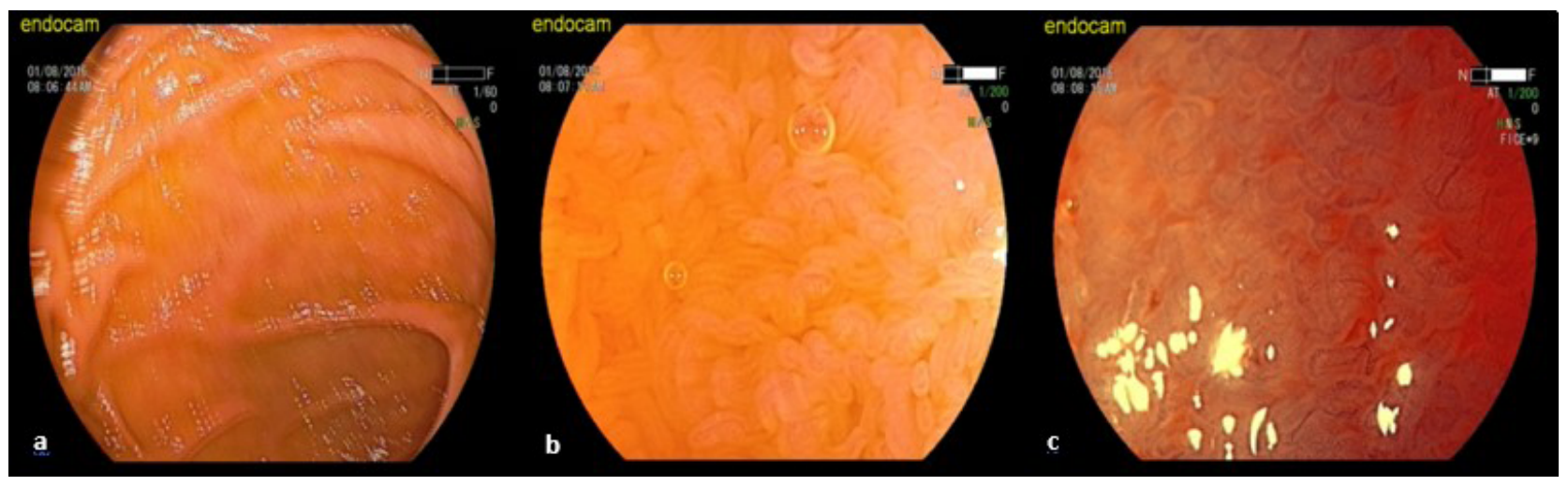

FICE method has $100 \%$ sensitivity and specificity in the diagnosis of CeD.

As CeD awareness increases, there is a search for more easily accessible and cost-effective diagnostic methods. Easy diagnosis methods are being developed with blood sampling from the fingertip, or urine and stool samples ${ }^{24}$. The sensitivity and specificity of our evaluation with magnified and magnified/FICE were found to be $100 \%$ in our group of 50 patients, with 10 of them being diagnosed with CeD. When the narrow-band imaging method and duodenal pathology results of $112 \mathrm{CeD}$ patients performed by Tabibian et al. ${ }^{29}$ were compared, the determination of villous atrophy was found to be significantly superior, similar to what was found in our study.

Since our study is prospective, it has some limitations, as follows. The number of patients is limited and we have no findings for magnified and magnified/ FICE data in March.
In conclusion, changes in the duodenal mucosa with magnified and magnified/FICE correlate with histopathological findings. In particular, detailed image quality can be achieved with FICE. By using magnified/FICE in addition to conventional WLE, changes in duodenal mucosa are examined in more detail, so false-negative results in individuals with normal duodenal mucosal appearance can be minimized.

\section{Authors' contribution}

Concept: SA. Design: SA, OBB. Supervision: HA. Materials: OBB, EC. Data collection and/or processing: SA. Analysis and/or interpretation: SA, OBB. Literature search: SA. Writing: SA, OBB. Critical reviews: SA, OBB, HA.

\section{Conflict of interest}

We have no conflict of interest. 


\section{RESUMO}

INTRODUÇÃO: A doença celíaca (DC) é uma doença autoimune que pode ter seu diagnóstico atrasado devido à presença de casos atípicos e assintomáticos na idade adulta. Neste trabalho, objetivamos estudar a frequência de DC e avaliar se as técnicas de endoscopia magnificada e magnificada/Fice (flexible spectral imaging color enhancement) contribuem para o diagnóstico em pacientes com deficiência sérica de ferro e vitamina B12.

MÉTODO: Foram avaliados prospectivamente 50 pacientes adultos (10 homens e 40 mulheres) com deficiência sérica de ferro e vitamina B12. Todos os pacientes foram submetidos a endoscopia digestiva alta pelo mesmo endoscopista. A segunda parte do duodeno foi avaliada com endoscopia com luz branca, magnificada e magnificada/Fice. As amostras de biópsia foram avaliadas pelo mesmo patologista. Os espécimes diagnosticados como DC foram classificados de acordo com os critérios de Marsh-Oberhuber modificado.

RESULTADOS: Dez dos 50 pacientes (\% 20) foram diagnosticados como DC. A idade média foi de $41 \pm 11$ anos (20-67 anos). Trinta por cento dos pacientes diagnosticados com DC apresentaram sintomas típicos de DC. Seis dos dez pacientes (60\%) diagnosticados com DC tinham imagens endoscópicas típicas sob endoscopia de luz branca. Todos esses dez pacientes (\% 100) apresentaram irregularidade das vilosidades, atrofia das vilosidades parciais ou atrofia das vilosidades totais consistentes com a DC com endoscopia magnificada e magnificada/Fice.

CONCLUSÃo: O uso prático da endoscopia magnificada/Fice permite diferenciar anormalidades mucosas do duodeno e minimizar os resultados falso-negativos que apresentam achados mucosais normais com a endoscopia convencional.

PalAVRAS-ChaVE: Doença celíaca. Deficiência de vitamina B 12. Deficiência de ferro. Aumento da imagem/métodos. Processamento de imagem assistida por computador.

\section{REFERENCES}

1. Marsh MN, Crowe PT. Morphology of the mucosal lesion in gluten sensitivity. Bailleres Clin Gastroenterol. 1995;9(2):273-93.

2. Oberhuber G. Histopathology of celiac disease. Biomed Pharmacother. 2000;54(7):368-72.

3. Stolte M, Meining A. The updated Sydney system: classification and grading of gastritis as the basis of diagnosis and treatment. Can | Gastroenterol. 2001;15(9):591-8.

4. Lebwohl B, Sanders DS, Green PHR. Coeliac disease. Lancet. 2018;391(10115):70-81.

5. Fasano A, Catassi C. Clinical practice. Celiac disease. N Engl J Med. 2012;367(25):2419-26.

6. Khatib M, Baker RD, Ly EK, Kozielski R, Baker SS. Presenting pattern of pediatric celiac disease. J Pediatr Gastroenterol Nutr. 2016;62(1):60-3.

7. Singh P, Arora S, Lal S, Strand TA, Makharia GK. Celiac disease in women with infertility: a meta-analysis. J Clin Gastroenterol. 2016;50(1):33-9.

8. Lo W, Sano K, Lebwohl B, Diamond B, Green PH. Changing presentation of adult celiac disease. Dig Dis Sci. 2003;48(2):395-8.

9. Gujral N, Freeman HJ, Thomson AB. Celiac disease: prevalence, diagnosis, pathogenesis and treatment. World J Gastroenterol. 2012;18(42):6036-59.

10. Singh P, Arora A, Strand TA, Leffler DA, Catassi C, Green PH. Global prevalence of celiac disease: systematic review and meta-analysis. Clin Gastroenterol Hepatol. 2018;16(6):823-36.

11. Elsurer R, Tatar G, Simsek H, Balaban YH, Aydinli M, Sokmensuer C. Celiac disease in the Turkish population. Dig Dis Sci. 2005;50(1):136-42.

12. Unsworth DJ, Lock FJ, Harvey RF. Iron-deficiency anaemia in premenopausal women. Lancet. 1999;353(9158):1100.

13. Corazza GR, Valentini RA, Andreani ML, D'Anchino M, Leva MT, Ginaldi $L$, et al. Subclinical coeliac disease is a frequent cause of iron-deficiency anaemia. Scand J Gastroenterol. 1995;30(2):153-6.

14. Schøsler L, Christensen LA, Hvas CL. Symptoms and findings in adult-onset celiac disease in a historical Danish patient cohort. Scand J Gastroenterol. 2016;51(3):288-94

15. Paez MA, Gramelspacher AM, Sinacore J, Winterfield L, Venu M. Delay in diagnosis of celiac disease in patients without gastrointestinal complaints. Am | Med. 2017;130(11):1318-23.

16. Akay S, Sezer SD, Binicier ÖB, Uzun M, Akar H. Dilemma in the diagnosis of celiac disease: case report. Turkiye Klinikleri J Intern Med. 2016;1(1):55-60.

17. Cappello M, Morreale GC, Licata A. Elderly onset celiac disease: a narrative review. Clin Med Insights Gastroenterol. 2016;9:41-9.
18. Tesei N, Sugai E, Vazquez H, Smecuol E, Niveloni S, Mazure R, et al. Antibodies to human recombinant tissue transglutaminase may detect coeliac disease patients undiagnosed by endomysial antibodies. Aliment Pharmacol Ther. 2003;17(11):1415-23.

19. O'Farrelly C, Kelly J, Hekkens W, Bradley B, Thompson A, Feighery C, et al. Alpha gliadin antibody levels: a serological test for coeliac disease. $\mathrm{Br}$ Med J (Clin Res Ed). 1983;286(6383):2007-10.

20. Rostom A, Dubé C, Cranney A, Saloojee N, Sy R, Garritty C, et al. The diagnostic accuracy of serologic tests for celiac disease: a systematic review. Gastroenterology. 2005;128(4 Supp| 1):S38-46.

21. Lewis NR, Scott BB. Meta-analysis: deamidated gliadin peptide antibody and tissue transglutaminase antibody compared as screening tests for coeliac disease. Aliment Pharmacol Ther. 2010;31(1):73-81.

22. Rubio-Tapia A, Hill ID, Kelly CP, Calderwood AH, Murray JA; American College of Gastroenterology. ACG clinical guidelines: diagnosis and management of celiac disease. Am J Gastroenterol. 2013;108(5):656-76.

23. Uyanikoglu A, Coskun M, Binici DN, Öztürk Y. The incidence of endoscopic celiac (gluten) disease in the Erzurum area in an adult population. Akademik Gastroenteroloji Dergisi. 2013;12(1):13-6.

24. Pohl I, May A, Rabenstein T, Pech O, Nguyen-Tat M, Fissler-Eckhoff A, et al. Comparison of computed virtual chromoendoscopy and conventional chromoendoscopy with acetic acid for detection of neoplasia in Barrett's esophagus. Endoscopy. 2007;39(7):594-8.

25. Pohl J, Nguyen-Tat M, Pech O, May A, Rabenstein T, Ell C. Computed virtual chromoendoscopy for classification of small colorectal lesions: a prospective comparative study. Am J Gastroenterol. 2008;103(3):562-9.

26. Yao K, Anagnostopoulos GK, Ragunath K. Magnifying endoscopy for diagnosing and delineating early gastric cancer. Endoscopy. 2009;41(5):462-7.

27. Cammarota G, Cesaro P, Cazzato A, Fedeli P, Sparano L, Vecchio FM, et al. Optimal band imaging system: a new tool for enhancing the duodenal villous pattern in celiac disease. Gastrointest Endosc. 2008;68(2):352-7.

28. Pasinszki T, Perrault JF, Murray |A, Papadakis KA, Enders FT, Gostout C|. Narrow band imaging evaluation of duodenal villi in patients with and without celiac disease: a prospective study. World J Gastrointest Endosc. 2019;11(2):145-54.

29. Tabibian JH, Perrault JF, Murray JA, Papadakis KA, Enders FT, Gostout C). Narrow band imaging evaluation of duodenal villi in patients with and without celiac disease: a prospective study. World / Gastrointest Endosc. 2019;11(2):145-54 